\title{
Effect of two milking systems on the milking characteristics, teat tissue changes and new infection rate of dairy cows
}

\author{
David E. GLEESON ${ }^{a *}$, Edmond J. O’CALlAGHAN ${ }^{\mathrm{a}}$, William J. MEANEYa, \\ Myles V. RATH \\ a Teagasc, Moorepark Production Research Centre, Fermoy, Co. Cork, Ireland \\ b Department of Animal Science, Faculty of Agriculture, University College Dublin, Ireland
}

(Received 20 October 2003; accepted 17 February 2005)

\begin{abstract}
Holstein-Friesian dairy cows $(\mathrm{n}=56)$ were assigned to either of two milking systems over a complete lactation. System WB consisted of a heavy cluster weight of $3.2 \mathrm{~kg}$ with a claw volume of $150 \mathrm{~mL}$, wide-bore tapered liners $(31.6-21.0 \mathrm{~mm})$ and a simultaneous pulsation pattern. System NB used a light cluster weight of $1.65 \mathrm{~kg}$ with a claw volume of $275 \mathrm{~mL}$, narrow-bore liners $(25.0$ $21.0 \mathrm{~mm}$ ) and an alternate pulsation pattern. All cows were managed as one herd and milked in an 80-degree side-by-side milking parlour, with a milk lift of $1.5 \mathrm{~m}$ above the cow standing. Comparison was made between systems for milking characteristics and intramammary infection. Ultrasonography was used to measure changes to various teat parameters and external teat condition was assessed visually. Mean milk yield, milking rate, peak milk flow-rate, gross milk composition, and somatic cell count were similar for both milking systems. However, milk yield tended to be higher (by $5.2 \% ; P=$ 0.09 ) at the morning milking with WB as compared to NB. There was a significant milking system $\times$ lactation stage interaction $(P<0.01)$ for somatic cell count and for peak milk flow-rate at the morning milking. There was no difference between milking systems in the incidence of clinical or sub-clinical mastitis, teat texture or colour. There was a significant lactation stage interaction $(P<0.001)$ for external teat diameter, cistern diameter and teat wall thickness. There was system $\times$ lactation stage interaction $(P=0.08)$ for teat diameter with the WB system tending to be higher as compared to the NB system, however these changes did not result in higher infection rates or have any deleterious effect on teat condition. The two milking systems gave satisfactory milking performance.
\end{abstract}

dairy cows / milking / milking systems / teat tissue / infection

Résumé - Effet de deux systèmes de traite sur les caractéristiques du lait, l'intégrité tissulaire des trayons et l'état sanitaire des vaches laitières. Un total de 56 vaches laitières HolsteinFrisonnes a été assigné à l'un ou l'autre des deux systèmes de traite sur une lactation entière. Le système WB était composé d'un faisceau-trayeur lourd de 3,2 $\mathrm{kg}$ avec une griffe d'une capacité de $150 \mathrm{~mL}$, de manchons à bout large $(31,6-21,0 \mathrm{~mm})$ et d'un dispositif de pulsation simultanée. Le système NB était, quant à lui, constitué d'un faisceau-trayeur léger de $1,65 \mathrm{~kg}$ avec une griffe d'une capacité de $275 \mathrm{~mL}$, de manchons à bout étroit $(25,0-21,0 \mathrm{~mm})$ et d'un dispositif de pulsation

* Corresponding author: dgleeson@ moorepark.teagasc.ie 
alternative. Tous les animaux ont été conduits en troupeau et traits dans une salle de traite côte à côte à $80^{\circ}$, avec une barre frontale à une hauteur de $1,5 \mathrm{~m}$ au-dessus de la position de la vache. Les caractéristiques du lait et l'infection intramammaire ont été comparés dans les deux systèmes. L'ultrasonographie a permis de mesurer les évolutions de divers paramètres du trayon, et l'état externe des trayons a été évalué visuellement. La production laitière moyenne, la quantité de lait, la vitesse de traite maximale, la composition brute du lait, et le comptage de cellules somatiques ont été semblables pour les deux systèmes de traite. Toutefois, la production laitière a été légèrement plus élevée (de $5,2 \% ; P=0,09)$ à la traite du matin avec WB comparé à NB. Il y a eu une interaction significative entre le système de traite $\times$ le stade de lactation $(P<0,01)$ pour la numération cellulaire et la vitesse de traite maximale à la traite du matin. Il n'y a eu aucune différence entre les systèmes de traite dans l'incidence de mammite clinique ou subclinique, la texture ou la couleur du trayon. Il $\mathrm{y}$ a eu une interaction significative entre le stade de lactation $(P<0,001)$ et le diamètre externe du trayon, le diamètre de la citerne et l'épaisseur de la paroi du trayon. Il y a eu une interaction significative entre le système de traite $\times$ le stade de lactation $(P=0,08)$ pour le diamètre du trayon avec le système WB qui tend à être plus élevé comparativement au système NB ; toutefois, ces changements n'ont eu aucune conséquence sur l'état sanitaire ou aucun effet délétère sur l'état du trayon. Les deux systèmes de traite ont donné des résultats de traite satisfaisants.

vache laitière / traite / système de traite / tissu du trayon / infection

\section{INTRODUCTION}

In Ireland cows are generally milked with milking machines using heavy clusters (3.0$3.2 \mathrm{~kg})$, wide-bore tapered liners $(31.6-$ $21.0 \mathrm{~mm}$ ) and simultaneous pulsation. Previous studies showed reduced liner slip levels [23] and a 6\% increase in milk yield using this principle [5]. A survey of milking machines by Hillerton et al. [12] also found a reduction in both strip yield and liner slip with this system. However, the milking principle, which is used widely on European farms, incorporates a light cluster weight $(1.65 \mathrm{~kg})$ and narrow-bore tapered liners $(25.0-21.0 \mathrm{~mm})$. In simulation studies, wide-bore tapered liners with simultaneous pulsation patterns gave a higher average milking vacuum as compared to narrow-bore liners using an alternate pulsation pattern [21, 22, 24]. Mean teat-end vacuum measured over a full cycle was 37.9 and $39.2 \mathrm{kPa}$ for wide-bore $(31.6-21.0 \mathrm{~mm})$ and narrow-bore liners $(25.0-21.0 \mathrm{~mm})$, respectively, at an average flow-rate of 4 litres per minute. However, vacuum at the teat-end, with the liner in the open position was 46.3 and $39.3 \mathrm{kPa}$, for wide-bore and narrow-bore liners, respectively. Higher milking vacuum may increase peak milk flow-rate [6], but will also increase thick- ness of the teat end and barrel [10]. Hamann [9] using the cutimeter method and Gleeson et al. [4] using ultrasongraphy showed an increase in teat diameter thickness after milking by widening the liner upper barrel bore. However, Spencer et al. [27] suggested that the ultrasonic method gave more consistent measurements than that of the cutimeter. De Koning and Ipema [2] previously used the ultrasonic method to compare the effect of two liner types on teattissue reaction and found some differences in respect to teat cistern diameter and teat wall thickness. Zecconi et al. [28] observed higher infection rates in quarters and a higher incidence of teat duct colonization, where teat end thickness changed by $>5 \%$. Machine milking can cause short-term changes in teat hardness and colour. It is suggested that colour changes can be exacerbated with the use of wide-bore liners, heavy clusters and high milking vacuum [19]. Hillerton et al. [13] suggested that teat condition was poorer in herds using heavy clusters in conjunction with manual cluster removal. Over-milking may be more important with regard to teat colour and texture changes than cluster type [14]. Teat-end hyperkeratosis is associated with an increased probability of new intra-mammary infection [20]. Lewis et al. [18] concluded that as 
hyperkeratosis increased in severity the prevalence of sub-clinical infection increased. Evaluation of teat-end hyperkeratosis may help to identify problems in relation to machine milking. Previous studies comparing the performance of liner types have involved short-term trials using Latin square designs $[2,7,25]$. In this present study, the objective was to compare the effect of the two alternate milking systems on milking characteristics, teat condition and new infection rate over a complete lactation.

\section{MATERIALS AND METHODS}

Fifty-six Holstein-Friesian dairy cows including forty-six in 1 st lactation, calved during a 10-week period from the 20th September to 6th December. Cows were assigned to two milking systems in pairs over a period of twelve weeks and within oneweek of calving. Cows were randomised to milking systems based on lactation number, one post-calving somatic cell count (SCC), milk yield and teat-end hyperkeratosis. Milking system WB consisted of a heavy cluster weight $(3.2 \mathrm{~kg}$ ) with a claw volume of $150 \mathrm{~mL}$, wide-bore tapered liners (31.6$21.0 \mathrm{~mm}$ ) and a simultaneous pulsation pattern $(4 \times 1)$. System NB used a light cluster weight $(1.65 \mathrm{~kg})$ with a claw volume of $275 \mathrm{~mL}$, narrow-bore tapered liners (25.0$21.0 \mathrm{~mm}$ ) and an alternate pulsation pattern $(2 \times 2)$. The liner makes were Dairymaster 916s and Delaval (harmony) 999007-02 for systems WB and NB, respectively. All cows were milked in a 14-unit, 80-degree sideby-side milking parlour, using id- $13.5 \mathrm{~mm}$ long milk tubes, with a milk lift of $1.5 \mathrm{~m}$ above the cow standing to a single milk-line (id-72 mm). Cows on this experimental farm were milked at intervals of $16 \mathrm{~h}$ (overnight) and $8 \mathrm{~h}$ (daytime) to minimise farm labour costs. Milking units and pulsation system were changed between treatment groups; with system WB operated first at each milking followed by system NB. Premilking teat preparation consisted of washing with warm running water and drying with individual paper towels. Milking char- acteristics including milk yield (kg), milking rate (kg milk per second) and peak milk flow-rate (litres per min) were recorded daily for each individual cow using Dairymaster Weigh-all electronic milk meters (Dairymaster, Causeway, Co Kerry, Ireland). Clusters were automatically removed as directed by electronic milk meters linked to a software program, when milk flow-rate dropped to 0.2 kilograms per minute with a delay time of $20 \mathrm{~s}$. Teats were disinfected by spraying with a chlorohexadine solution after cluster removal. The pulsation rate was 60 cycles per min and the pulsation chamber phases as defined by ISO [17] were $\mathrm{a}=$ $18.3 \%, 17.0 \%, b=46.8 \%, 51.4 \% ; c=11.5 \%$, $11.8 \%$; and $\mathrm{d}=23.4 \%, 19.8 \%$ for $\mathrm{NB}$ and WB milking systems, respectively at all milkings. The system vacuum levels were set at $48 \mathrm{kPa}$ and the system vacuum reserve was 870 litres per min. Teat-cup liners were replaced approximately 120 days (20th January) after the start date which was equal to approximately 1060 cow milkings. Liners were not tensioned during the study.

Cows were managed as one herd for the complete lactation and were fed indoors on a grass/maize silage diet for 180 days postcalving and outdoors on grass for the remainder of the lactation. Cows were individually removed from treatment when yields dropped to $7.0 \mathrm{~kg}$ per day or within 10 weeks of the next expected calving date. Milk yield, milking rate, and peak milk flow-rate are presented as mean daily measurements for 42 weeks of lactation.

\subsection{Milk composition and somatic cell count}

Gross composition (fat, protein and lactose concentration) was measured weekly on composite milk samples taken at morning and afternoon milkings, using the Milkoscan 203 (Foss Electric, DK 3400-Hillerod, Denmark). An individual bulk cow sample (morning milking) was also analysed for SCC using the Bentley Somacount 300 on alternate weeks. Fat, protein and lactose concentration and log-transformed SCC are presented as mean daily data for the 
42 weeks of lactation. Where the bulk cow milk sample indicated a SCC $>300 \times 10^{3}$ per $\mathrm{mL}$, individual quarter milk samples were taken in an aseptic manner and the milk samples were examined using the I.D.F [15] guidelines for microbiological analysis. Milk from individual quarters was also collected every two weeks for SCC analysis. Milk samples taken post-calving, which indicated a SCC $>300 \times 10^{3}$ per $\mathrm{mL}$ and/or quarters treated for clinical mastitis prior to allocation to milking system were excluded from the data set. Quarters were considered clinically infected if the milk was visibly abnormal or if quarters had signs of inflammation. A timerate lag of 8 days was used for a new case in an animal having a previous case of clinical mastitis. When quarters showed signs of clinical mastitis, individual quarters were milk sampled, typed for pathogens and treated with an antibiotic for three consecutive milkings. When an individual quarter $\mathrm{SCC}$ was $>300 \times 10^{3}$ per $\mathrm{mL}$ and pathogens were isolated, the quarter was considered to have a new sub-clinical infection. Sub-clinical infections, which subsequently became clinical, were excluded from the sub-clinical data set. Data for clinical mastitis is presented as the number of cases and the incidence rate of cases for 56-day lactation periods. The incidence rate is defined as the number of cases of mastitis divided by the population risk time. Subclinical mastitis is reported as the number of cases of new infection.

\subsection{Teat condition}

Teat barrels were classified for teat texture by manual palpation and for teat colour by visual assessment, by an operator unfamiliar with the milking treatments. All teats were examined on consecutive days during mid-lactation and were classified within one minute of cluster removal and scored for texture as soft or firm. Teats were classified for hyperkeratosis after cluster removal each month, during the lactation by one operator using a headlamp to illuminate the teatends. Results were reported elsewhere [8].
An Aloka 500v-ultrasound scanner with a $7 \mathrm{MHz}$ linear probe was used to measure changes in various teat parameters on three occasions during early, mid and late lactation. Eight docile cows including four in their 1st lactation were chosen from each treatment for these measurements. The procedure involved filling a Femidom-condom with warm water and placing it around the cow's teat. A film of lubricating gel was placed on the probe head to improve contact with the condom. The probe was placed in a vertical position against the teat wall until a clear image of the teat canal and cistern appeared on the screen. When a clear picture was obtained, the image was frozen on screen. Images of teats were stored on videocassette and these were subsequently measured on screen. Pre-milking teat scan measurements were recorded from all four teats at the morning milking. Teats were washed and dried with paper towels before the initial measurement was taken.

The ultrasonic method and procedures used for this measurement are described elsewhere [7]. The measurements recorded included teat canal length (TCL), external teat diameter at the top of the teat canal (TD), cistern diameter (CD), and teat wall thickness (TWT). Measurements of teat tissue $(\mathrm{mm})$ are presented as the mean changes (increases or decreases) in values per teat directly after milking compared to premilking values. Teat length (TL) was measured by placing the teat into a calibrated transparent tube.

\subsection{Statistical analyses}

Statistical analysis of data was performed using Genstat [3]. Cows were blocked in pairs according to lactation number, post calving SCC, milk yield and teat-end hyperkeratosis. The statistical model was a mixed model with blocks as the random effect and treatment as the fixed effect and with repeated measures. A Wald test was used for accessing fixed model terms. Comparison was made between systems for milk yield, milking rate ( $\mathrm{kg}$ milk per second), peak milk 
Table I. Mean daily milk yield, milking rate, peak milk flow-rate, gross milk composition and somatic cell count throughout lactation for two milking systems.

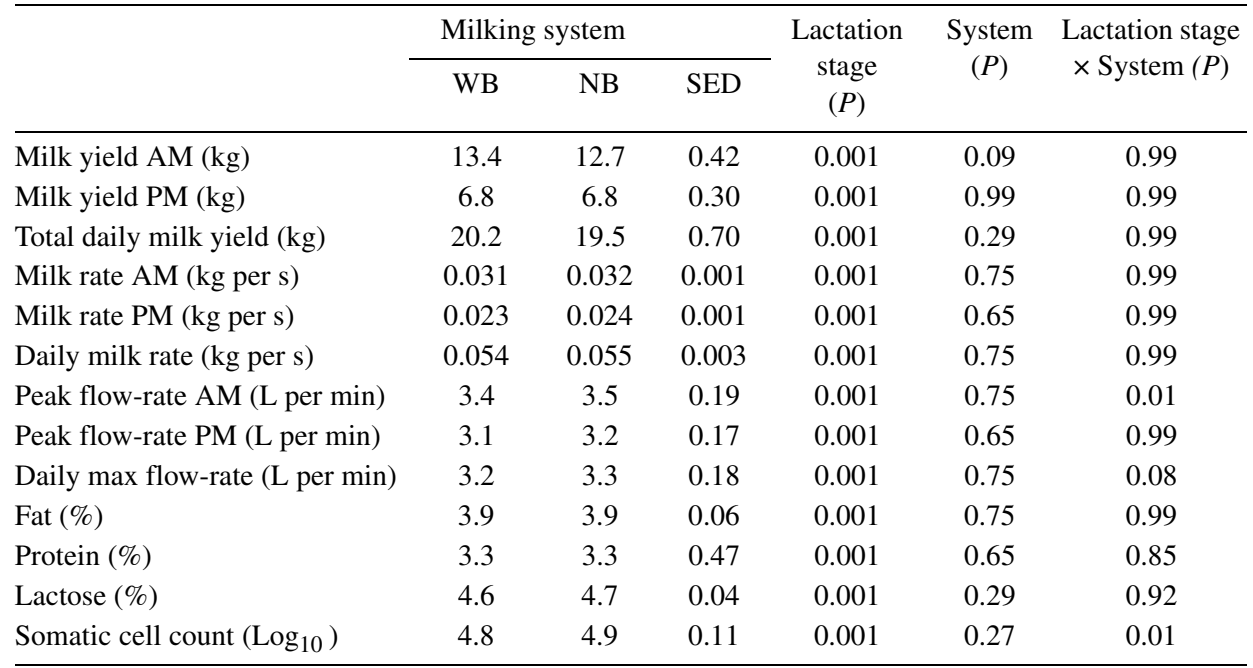

SED: standard error of differences.

WB: System WB consisted of a heavy cluster weight of $3.2 \mathrm{~kg}$ with a claw volume of $150 \mathrm{~mL}$, wide-bore tapered liners (31.6-21.0 $\mathrm{mm}$ ) and a simultaneous pulsation pattern;

NB: System NB used a light cluster weight of $1.65 \mathrm{~kg}$ with a claw volume of $275 \mathrm{~mL}$, narrow-bore liners $(25.0-21.0 \mathrm{~mm})$ and an alternate pulsation pattern.

flow-rate and gross composition for fat and protein. Somatic cell counts for each individual cow were log transformed and averaged for each treatment. The analysis of ultrasonic teat tissue measurements was performed on the mean values of all four teats for each teat parameter measured at early, mid and late lactation stages. Clinical mastitis is reported as the incidence rate of clinical mastitis per day at risk for various stages of lactation using the IDF [16] recommendations for presentation of mastitis related data. Mean teat-tissue changes were compared by analysis of variance.

\section{RESULTS}

\subsection{Milking characteristics}

The average lactation milk yield per cow for all cows was 5465 and $5267 \mathrm{~kg}$ and for 1st lactation cows was 5256 and $5148 \mathrm{~kg}$ for
WB and NB milking systems, respectively. The length of lactation (39 weeks) and the mean daily milk yields over the complete lactation (Tab. I) were similar for both milking systems. However, the mean daily milk yield tended to be higher (by $5.2 \% ; P=0.09$ ) for the WB system at the morning milking as compared to the NB system (Tab. I, Fig. 1a). There was a significant $(P<0.001)$ effect of lactation stage on milk yield, milking rate, peak milk flow-rate, milk composition and somatic cell count.

There was no difference between milking systems for milking rate or peak milk flow-rate (Tab. I), however there were lactation stage $\times$ milking system interactions $(P<0.01)$ for peak milk flow-rate at the morning milking (Fig. 1b). The WB milking system tended to have a higher milk flow-rate during the early part of lactation in contrast to the NB system, which had a higher flow-rate during the latter part of lactation. 
(a) Milk Yield

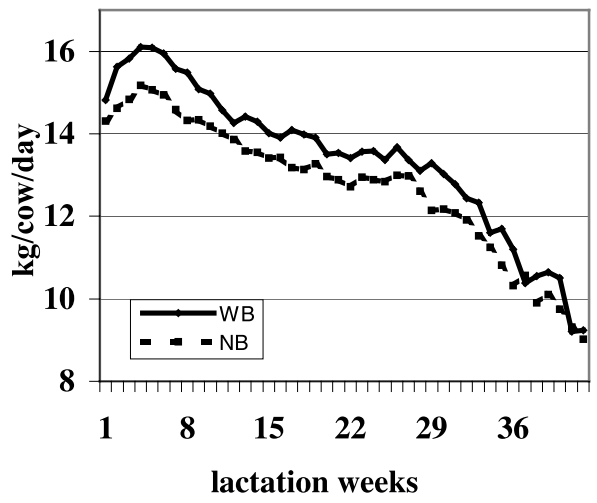

(b) Peak milk flow

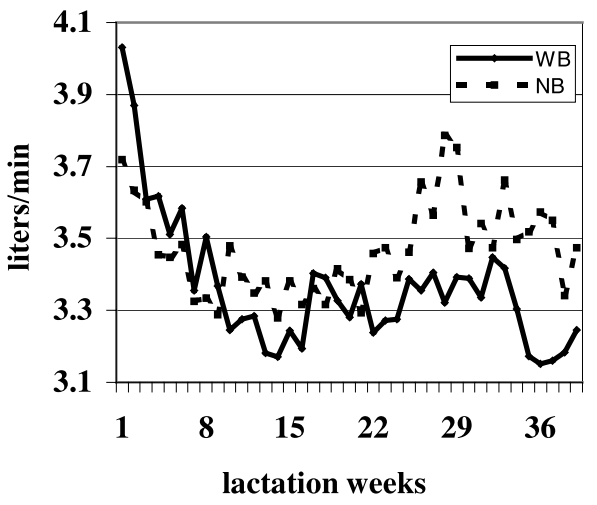

(c) Somatic cell count

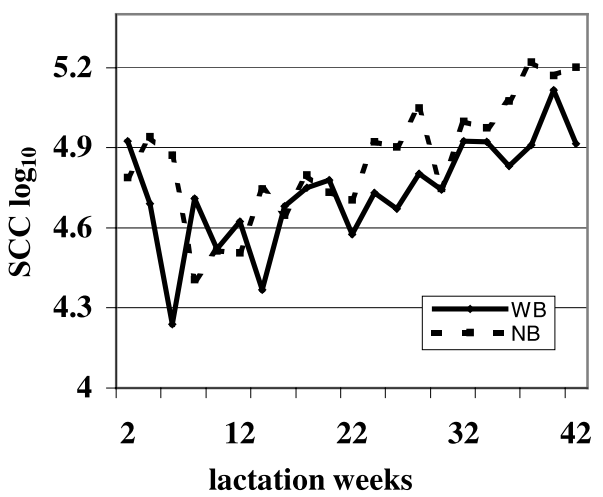

Figure 1. Daily milk yield (a) and peak milk flow-rate (b) at the morning milking and somatic cell count (c) biweekly throughout lactation for WB and NB milking systems.
Milk fat, protein and lactose contents were similar for both milking systems. While fat and protein yields were $3.5 \%$ higher with the WB system due to the higher milk production these differences were not significant.

\subsection{Incidence of mastitis}

There was no statistical difference in $\log _{10}$ SCC between milking systems (Tab. I). However, there was a significant $(P<0.01)$ lactation stage $\times$ system interaction for $\mathrm{SCC}$ (Fig. 1c). There was no difference in the incidence of clinical mastitis or sub-clinical mastitis between systems. The number of cows with clinical mastitis was 9 ( 15 cases) and 13 (16 cases) for WB and NB milking systems, respectively (Tab. II). The incidence rate of clinical mastitis tended to be highest for the WB system during lactation days 57 to 168 and for the NB system during days 113 to 168 . There were 5 cows ( 6 cases) and 9 cows (11 cases) with sub-clinical mastitis for WB and NB milking systems, respectively. There were no differences between treatments in the pathogen type in infected quarters and Staphylococcus aureus was the most common pathogen isolated.

\subsection{Teat condition}

There was no difference in teat texture or colour between milking systems. The percentage of teats classified as soft was 34 and 32 for WB and NB systems, respectively. The number of normal and red coloured teats is presented as a percentage of light coloured teats. The percentage of teats classified as normal was 78 and 73 and red coloured was 22, 27 for WB and NB systems, respectively. Ultrasonic values for the various teat parameters were similar for both milking systems. There was a lactation stage interaction $(P<0.001)$ for teat diameter, cistern diameter and teat wall thickness (Tab. III). Changes in measurements to these parameters decreased with stage of lactation. There was a lactation stage $\times$ system interaction for teat diameter $(P=0.08)$ with WB tending to have increased changes 
Table II. Incidence rate of cases of clinical mastitis for WB and NB milking systems.

\begin{tabular}{|c|c|c|c|c|c|c|}
\hline \multirow[t]{2}{*}{ Lactation stage } & \multicolumn{2}{|c|}{ Days at risk } & \multicolumn{2}{|c|}{ No. of cases } & \multicolumn{2}{|c|}{ Incidence rate } \\
\hline & WB & NB & WB & NB & WB & NB \\
\hline $0-56$ days & 784 & 760 & 0 & 3 & 0.00000 & 0.00395 \\
\hline 57-112 days & 1408 & 1432 & 6 & 3 & 0.00426 & 0.00209 \\
\hline 113-168 days & 1512 & 1528 & 7 & 6 & 0.00463 & 0.00393 \\
\hline 169-224 days & 1568 & 1552 & 0 & 2 & 0.00000 & 0.00129 \\
\hline 225-280 days & 1456 & 1456 & 0 & 0 & 0.00000 & 0.00000 \\
\hline 281-336 days & 1104 & 1096 & 2 & 2 & 0.00181 & 0.00181 \\
\hline Total in lactation & 7832 & 7824 & 15 & 16 & 0.00192 & 0.00204 \\
\hline
\end{tabular}

For abbreviations, see Table I;

Incidence rates are shown for 56-day lactation periods.

Table III. Effect of WB and NB milking systems on changes to various teat parameters (value just after milking - value just before milking; $\mathrm{mm}$ ), for early, mid and late stages of lactation.

\begin{tabular}{|c|c|c|c|c|c|c|}
\hline & \multicolumn{2}{|c|}{ Milking system } & \multirow[b]{2}{*}{ SED } & \multirow{2}{*}{$\begin{array}{l}\text { Lactation } \\
\text { stage }(P)\end{array}$} & \multirow{2}{*}{$\begin{array}{l}\text { System } \\
\qquad(P)\end{array}$} & \multirow{2}{*}{$\begin{array}{l}\text { Lactation stage } \times \\
\quad \text { System }(P)\end{array}$} \\
\hline & WB $(n=24)$ & $\mathrm{NB}(\mathrm{n}=24)$ & & & & \\
\hline Canal length & 1.71 & 1.93 & 0.39 & 0.70 & 0.59 & 0.31 \\
\hline Teat diameter & 1.29 & 1.04 & 0.26 & 0.004 & 0.36 & 0.08 \\
\hline Cistern diameter & -4.73 & -4.64 & 0.49 & 0.001 & 0.86 & 0.12 \\
\hline Wall thickness & 1.89 & 1.77 & 0.16 & 0.001 & 0.46 & 0.22 \\
\hline Teat length & 7.80 & 5.60 & 1.90 & 0.53 & 0.26 & 0.96 \\
\hline
\end{tabular}

For abbreviations, see Table I;

$\mathrm{n}=$ number of cows.

at mid lactation stage as compared to the NB milking system. The mean morning milk yields per cow (eight cows per treatment) at early lactation stage were 13.2 and $14.3 \mathrm{~kg}$, at mid lactation stage were 11.4 and $12.7 \mathrm{~kg}$ and at late lactation stage were 9.8 and $11.3 \mathrm{~kg}$, for NB and WB milking systems respectively.

\section{DISCUSSION}

A tendency, toward higher milk yield $(5.2 \%)$ at morning milking for WB as compared to the NB milking system was observed in this study and is consistent with the data of a previous experiment $(5.9 \%$; Gleeson and O'Callaghan [5]). The reduc- tion in milk yield with light clusters at the morning milking may be due to the volume of milk per cow as there were no differences between cluster types at the evening milking when milk yield per cow was lower. In commercial farms in Ireland the milking interval is generally in the range 1012 hours and the reduction in daily milk yield with NB may be greater.

There was no difference between milking systems for milking rate. Rasmussen and Madsen [26] concluded that when using lightweight clusters, cluster-on time was reduced. However, cluster-on times in the current study were not influenced by cluster weight. While differences in the peak flowrate between systems were small, the peak flow-rate for the morning milking was higher 
than that for the evening milking over the entire lactation. The higher flow-rate at the morning milking was probably due to the higher morning milk yield. The lower flowrate with the WB cluster during the latter part of lactation may indicate a drop in liner tension when these liners are aged. The significant effect of lactation stage on milk yield, milking rate, peak milk flow-rate and SCC could be expected as milk yield per cow was reduced as the lactation progressed.

The slightly higher number of cases of sub-clinical mastitis with the NB system may account for the arithmetically higher somatic cell counts recorded for lactation stage with this system. However, while there was a significant milking system $\times$ lactation stage interaction for SCC, the levels recorded for both systems remained within EU quality standards regulations for raw milk [1]. Changes in teat colour with milking systems using wide-bore liners, shown by Hillerton et al. [13] were probably more related to different levels of over-milking rather than the milking system used. Clusters were removed in the current study when milk flow-rate dropped to $0.2 \mathrm{~kg}$ per min and therefore, over-milking was not an issue. This may explain why there were no differences in teat colour or teat texture between systems. When teat colour or texture changes are used to compare the performance of commercial milking machines it is important that clusters are removed at the same milk flow-rate and the experimental configuration of the milking unit are similar to those recommended by the manufacturer.

Changes in teat diameter thickness (TD) were numerically lower for the NB system as compared to the WB system. A previous study by Gleeson et al. [4] showed a significant increase in TD for the WB liner as compared to a narrow-bore liner with upper barrel dimensions of $21.0 \mathrm{~mm}$. However, these differences were demonstrated in a low-level milking system. Gleeson et al. [7] showed increased cistern diameter (CD) and teat wall thickness (TWT) changes when high milk yields were harvested. This may explain the interaction between stage of lactation and these parameters in this study, as the milk yield declined with successive measurements during the lactation. TD changes of $5.4 \%$ and $4.4 \%$ for $\mathrm{WB}$ and NB milking systems, respectively, were close to the $+/-5 \%$ range as recommended by Hamann [11] as a guideline of good milking machine function. While changes in TD tended to be higher $(P<0.08)$ with lactation stage with the WB system as compared to the NB system, these changes did not result in higher infection rates or have any deleterious effect on teat condition. The higher mean vacuum at the teat-end with the WB system did not influence milking rate or the peak milk flow-rate.

\section{ACKNOWLEDGEMENTS}

The authors thank Mr. D. O'Grady and J. Flynn for technical assistance; authors also wish to thank Ms. P. Reid for statistical analysis. The support of Irish Dairy farmers (Dairy Levy Fund) is acknowledged. The research was partfunded by European Union Structural Funds (EAGGF).

\section{REFERENCES}

[1] Anon, Council Directive 92/46/EEC, Official J. European Communities No. L268/2, 1992, pp. 1-32.

[2] De Koning C.J.A.M., Ipema A.H., Milking characteristics of two liners, Proceedings of the International Symposium on Robotic Milking, Lelystad, Netherlands, 17th-19th August, 2000, pp. 58-59.

[3] Genstat, 5 Release 3.2., Lawes Agricultural Trust, Rothamsed Experimental Station, 1995.

[4] Gleeson D.E., O'Callaghan E., Effect of liner design and plant vacuum level on bovine teattissue reaction, Irish J. Agric. Food Res. 37 (1998) 135.

[5] Gleeson D.E., O'Callaghan E., Effect of two milking principles on the milking characteristics of dairy cows, Irish J. Agric. Food Res. 39 (2000) 482. 
[6] Gleeson D.E., O'Callaghan E., Effect of system vacuum level on bovine teat-tissue reaction and milking characteristics, Proceedings, Annual Meeting of National Mastitis Council, Inc. Arlington, Virginia, 14th-17th February, 1999, Vol. 38, pp. 209-210.

[7] Gleeson E., O'Callaghan E.J., Rath M., Effect of milking on bovine teat tissue as measured by ultrasonography, Irish Vet. J. 55 (2002) 1000-1004.

[8] Gleeson D.E., O'Callaghan E., Rath M., The effects of genotype, milking time and teat-end vacuum pattern on the prevalence and severity of teat-end hyperkeratosis, Irish J. Agric. Food Res. 42 (2003) 195-203.

[9] Hamann J., Physio-pathological aspects of machine milking, Proceedings of the International Symposium of Bovine Mastitis, Milan, 1992, pp. 53-67.

[10] Hamann J., Mein G.A., Wetzel S., Teat tissue reactions to milking. Effects of vacuum level, J. Dairy Sci. (1993) 1040-1056.

[11] Hamann J., Machine induced teat Tissue Changes and New Infection Risk, Proceedings of International Conference on Machine Milking and Mastitis, Silver Springs Hotel, Cork, 23rd May 1997, pp. 89-109.

[12] Hillerton J.E., Ohnstad I., Bainnes J., Relationship of cluster performance to postmilking teat condition, Proceedings of Annual Meeting, National Mastitis Conference, St Louis, 1998, Vol. 37, pp. 75-84.

[13] Hillerton J.E., Ohnstad I, Bainnes J, Leach K.A., Changes in cow teat tissue created by two types of milking cluster, J. Dairy Res. 67 (2000) 309-317.

[14] Hillerton J.E., Pankey J.W., Pankey P., Effect of over-milking on teat condition, J. Dairy Res. 69 (2002) 81-84.

[15] International Dairy Federation, in: Bulletin, Laboratory methods for use in mastitis work, International Dairy Federation, Brussels, 1981, pp. 1-7.

[16] International Dairy Federation, in: Bulletin, Recommendations for presentation of mastitis-related data. Part 2: Clinical mastitis, International Dairy Federation, Brussels, 1997, p. 321.

[17] ISO 3918, Milking machine installationsVocabulary, International Organization for Standards, Geneva, Switzerland, 1996, 39 p.
[18] Lewis S., Cockcroft P.D., Bramley R.A., Jackson P.G., The likelihood of sub-clinical mastitis in quarters with different types of teat lesions in the dairy cow, Cattle Practice 8 (2002) 293-299.

[19] Mein G.A., (Teat club international, I.D.F), Evaluation of Bovine Teat Condition in Commercial Dairy Herds: Non-infectious Factors, Proceedings of 2nd International Symposium on Mastitis and Milk Quality, Vancouver, BC, Canada, 13th-15th September, 2001, pp. 347351.

[20] Neijenhuis F., (Teat club international, I.D.F), Evaluation of Bovine Teat Condition in Commercial Dairy Herds: Relationship between Teat-End Callosity or Hyperkeratosis and Mastitis, Proceedings of 2nd International Symposium on Mastitis and Milk Quality, Vancouver, BC, Canada, 13th-15th September, 2001, pp. 362-366.

[21] O'Callaghan E.J., Gleeson D.E., Measurement of vacuum stability in milking units during simulated milking, Irish J. Agric. Food Res. 38 (1999) 272.

[22] O'Callaghan E.J., Gleeson D.E., Evaluation of milking systems in terms of new mastitis risk, teat tissue reactions and milking performance, End of project report. 4505, Teagasc, November, 2000, $16 \mathrm{p}$.

[23] O'Callaghan E., Measurement of liner slips, milking times and milk yield, J. Dairy Sci. 79 (1996) 390-395.

[24] O'Callaghan E., Measurement of vacuum in the cluster, using a milkflow simulator, Irish J. Agric. Food Res. 37 (1998) 137.

[25] O'Shea J., O'Callaghan E., Experiments on milking machine components at Moorepark 1978-1980, An Foras Taluntais, Dublin, Ireland, 1982, pp. 200-211 (ISBN 0-905442-68-7).

[26] Rasmussen M.D., Madsen N.P., Effects of Milkline Vacuum, Pulsator Airline Vacuum and Cluster Weight on Milk Yield, Teat Condition, and Udder Health, J. Dairy Sci. 83 (2000) 77-84.

[27] Spencer S.B., Griel L.C., Goldberg J.J., The use of Ultrasonography to measure teat congestion, Proceedings of National Mastitis Council Meeting, 1996, Vol. 35, pp. 172-173.

[28] Zecconi A., Hamann J., Bronzo V., Ruffo G., Machine-induced teat tissue reactions and infection risk in a dairy herd free of contagious mastitis pathogens, J. Dairy Res. 59 (1992) 265-271. 